\title{
ADVANCING ADJUSTMENT IN THE PROGRESS OF ACHIEVE THE ENGLISH PHONOLOGICAL COMPONENT
}

\section{Reingold, R.}

Department Of Philology, Central South University ,China

\section{ABSTRACT}

The motivation behind this paper is to introduce the outcomes gotten from a mixed learning educational involvement with the English Phonetics and Phonology classes, at Facultad de Filosofía Humanidades y Artes, Universidad Nacional de San Juan, Argentina. In this experience, interests identified with the instructing at more elevated level schooling and the utilization of innovative assets combine. Two issues will be tended to: a) the utilization of the email and the execution of an interpersonal interaction site, Facebook, the two of them utilized for scholarly purposes; and b) the aftereffects of an overview which was controlled to understudies to assess their conclusions about the value of these assets. As college instructors, we are delicate to the progressions that our general public is encountering in regards to data and correspondence advances (ICTs). The consolidation of mechanical assets of the Web 2.0 to curricular units, some way or another produces disturbances to conventional learning conditions and opens up a scope of conceivable outcomes which make it simpler for understudies to fabricate and deal with information in an unexpected way.

KEYWORDS:- English Phonetics, Phonology classes, Communications, Technology

\section{INTRODUCTION}

The breakdown of conventional situations and the presentation of new thoughts of reality to the interior of learning circumstances in advanced education, has advanced the test of building learning conditions that display various opportunities for producing information and handling it. The utilization of Information and Communications Technology (ICT) requires the plan of inventive strategies that offer better approaches to additional cutting-edge learning rehearses. Subsequently, a reestablishment of curricular plans is forced to satisfy the needs of the objective instructive local area that is turning out to be more information based and set apart by a forever expanding stream of data. As educators of English Phonetics and Phonology at Facultad de Filosofía, Humanidades y Artes, Universidad Nacional de San Juan, Argentina, we imagined the requirement for adjustment to upgrade the obtaining of the English phonological part. Subsequently, we have reexamined the ideas supporting our training rehearses with the goal that they could turn out to be all the more hypothetically educated and all the more suitably contextualized.

\section{Methods}

Participants This work depicts a b-learning experience did with thirty second year understudies going to the subject English 
CURRENT RESEARCH JOURNAL OF PHILOLOGICAL SCIENCES 2(5): 22-23,

May 2021 DOI: https://doi.org/10.37547/philological-crjps-02-05-07

ISSN 2767-3758

(C)2021 Master Journals

Crossref dof 81 Google

Accepted25th May, 2021 \& Published 28 ${ }^{\text {th }}$ May, 2021

Phonetics and Phonology, at school level. The members ran in age from 19-30. The motivation behind this experience was to proceed with the mix of innovation in our instructive setting with the purpose of enhancing the interaction of procurement of the English phonological segment.

\section{Discussion}

Information got to depict the consequences of this experience furnished us with fundamental bits of knowledge and an underlying feeling of the results. For the investigation, rates were utilized to portray understudies' perspectives and discernments and benefits and impediments. This starter data will be utilized for resulting investigation periods of the examination. Results got from the email addresses will be introduced initially. They will be trailed by the outcomes comparing to similar inquiries for Facebook.

\section{Conclusion}

This paper is the consequence of an exploratory inquiry wherein the issue of coordinating mechanical instruments in our English Phonetics and Phonology courses has been tended to. Inside the structure of mixed learning, we have thought about not just the difficulties presented by the utilization of new advances yet additionally on the significance of the new types of cooperation created in the 2.0 learning climate. This experience included complex adjustment, where coordinated and offbeat correspondences existed together and added to the configuration of another instructive situation.

\section{REFERENCES}

1. Al-Hazza T. \& Bucher T. K., 2008. Competencia advanced: Para qué, quién, dónde y cómo debe enseñarse. REVISTA AULA. De Innovacción educativa.182, p. 5.

2. Ben -Rafael, E. \& Peres, Y., 2009.0pening Facebook: How to Use Facebook in the College Classroom. In: Society for Information Technology and Teacher Education Conference. Charleston, South Carolina, Mar 02, 2008.

3. Haviv-Barak, A., Bekerman, T. \& Bilu, Y., 1965. The Origins of Intelligence in Children. New York: International Universities Press.

4. Salinas, J., 1998. Rol del profesorado universitario bet los cambios de la time advanced. Perfeccionamiento Integral del Profesor Universitario. In: Primer Encuentro Iberoamericano. Caracas, Venezuela, July 21-22, 1998.

5. Inbar, O., Donitsa-Schmidt, S., \& 2008. Mixed picking up: Using innovation in and past the classroom.Oxford:

6. Shohamy, E 1961. Thought and Language. Cambridge, Mass: MIT Press. 